\title{
Attitude and knowledge towards prescription of generic drugs: online study across Telangana
}

\author{
Sumana Sen ${ }^{1 *}$, Bandari Naveen Kumar²
}

\begin{abstract}
${ }^{1}$ Department of Pharmacology, ${ }^{2} 8^{\text {th }}$ semester MBBS student, Apollo Institute of Medical Sciences and Research, Jubilee hills, Hyderabad, Andhra Pradesh India
\end{abstract}

Received: 25 June 2020

Revised: 03 August 2020

Accepted: 05 August 2020

\section{*Correspondence:}

Dr. Sumana Sen,

Email: sumanadrsen@gmail.com

Copyright: (c) the author(s), publisher and licensee Medip Academy. This is an open-access article distributed under the terms of the Creative Commons Attribution Non-Commercial License, which permits unrestricted non-commercial use, distribution, and reproduction in any medium, provided the original work is properly cited.

\section{ABSTRACT}

Background: Generic drugs are similar in terms of strength, safety and therapeutic benefit as compared to innovator counterparts. Generics have a favourable financial profile and a positive effect on medication adherence. Palpable change was not observed with the use of generics. This study has been designed to gauge the knowledge and attitude concerning generic drugs among medical students in their $5^{\text {th }}$ semester of MBBS course and interns in the final six months of their compulsory rotatory residential internship (CRRI) program in the state of Telangana.

Methods: It was a cross sectional, online-questionnaire based study across medical colleges in Telangana. The questions were designed with the help of Google forms and the website links were circulated to the participants through students and interns' whatsapp groups.

Results: $95.1 \%$ of interns and $92.7 \%$ of students had knowledge of generic drugs. Significant number of students had a notion that brand drugs are for serious illnesses. Majority in both the groups maintained a neutral opinion when it came to mandatory prescribing of generics.

Conclusions: Our study revealed a similar knowledge level about generic in both the groups and $40.9 \%$ of interns and $41.4 \%$ of students had a knowledge score of more than or equal to 80 . Interns didn't agree with incentivisation of brand drugs. $37.9 \%$ of interns and $32.3 \%$ of students had an attitude score of more than or equal to 80 . Therefore implementation of certain practices like stocking of more generics at medical college pharmacies, more research and incentivisation of generic use can translate into a rise of generic usage.

Keywords: Attitude score, Generic drugs, Knowledge score, Online study, Telangana

\section{INTRODUCTION}

The term 'generic drug' is defined by the World Health Organization (WHO), to mean a pharmaceutical product that is usually intended to be interchangeable with an innovator product. It can be manufactured without a licence from the innovator company and is marketed after the expiry date of the patent or other exclusive rights. ${ }^{1}$ No sooner a new drug/molecule come to light, the concerned company called the innovator company, has to file for a patent to protect against other organizations making similar molecules and selling the same. "A generic drug product that should have the same active ingredient, strength, dosage form, route of administration, quality, performance characteristics and intended use as the innovator drug". In the United States of America, when a generic molecule undergoes the process of approval, it has to meet rigorous standards established by the US FDA (Food and Drug Administration) with respect to identity, strength, quality, purity, and potency as generic drug. ${ }^{2}$

There is a need to know the difference between the terms 'generic drug' and 'generic nomenclature' as well. In 
India, majority of the drugs are 'branded generics 'which the pharmaceutical companies market with their specific brand/trade name.

In 2008, government of India had started the 'Jan Aushadhi' scheme under department of Pharmaceuticals. This was done to promote the use of generic drugs and thereby reduce the financial burden associated with the Indian healthcare system. Generic drugs are approximately 30-80\% less expensive than the innovator molecules. $^{3}$ They can have a positive impact on medication adherence due to less financial burden. Amendments have been brought about in Rule 65 (11A) of the Drugs and Cosmetics Act, 1940, wherein liberty has been given to dispense generic drugs against branded ones. Central Drugs Standard Control Organization (CDSCO), the main drug licensing authority in India has issued guidelines for bioavailability (BA)/bioequivalence (BE) studies as well. ${ }^{4}$ This is done to ensure purity, potency, efficacy and bioequivalence of the generic drugs. Medical Council of India (MCI) in its regulations (professional conduct, etiquette and ethics) in clause 1.5 stated that "Every physician should, as far as possible, prescribe drugs with generic names legibly and preferably in capital letters and he/she shall ensure that there is a rational prescription and use of drugs". 5 Guidelines by MCI have not been able to bring out a major change.

The success and implementation of use of generic drugs has to be interplay of regulators and healthcare providers/ clinicians. There seems to be lacunae existing among healthcare providers and this lack of trust percolates among patients as well. There has to be a metamorphosis in clinicians and it should start early from the phase of a medical student itself. They are taught about generic drugs in their $2^{\text {nd }} / 3^{\text {rd }}$ year of MBBS course, but after they pass out (internship) the concepts and practical application of prescribing generic drugs evaporate. Neither any importance is given in the medical post graduation courses thereafter, regarding generics. This is so very relevant in a country like India.

Robust efforts should be made for in depth understanding of this concept of generic drugs. This should go on in sync with government regulations. An example can be taken from United States Food and Drug Administration and its Orange Book. It provides updated information on generic drugs and their therapeutic equivalence evaluations on a monthly basis. ${ }^{6}$

Continuous effort should be in place to improve the outlook of medical students not only in Pharmacology but thereafter in clinical practice as well. Keeping this in mind this study has been designed to gauge the knowledge and attitude concerning generic drugs among medical students in their $5^{\text {th }}$ semester of MBBS course and those in the final six months of their compulsory rotatory residential internship (CRRI) program.

\section{METHODS}

It was a cross sectional, non-interventional, onlinequestionnaire based study conducted by the department of Pharmacology of Apollo institute of medical sciences and research, Hyderabad. It was initiated after approval from institutional research committee. The study period was from December 2019 to May 2020. The questionnaire included a set of twenty questions to assess the attitude and knowledge among four hundred participants. The participants comprised of two groups. One group was medical undergraduate students who had completed their $2^{\text {nd }}$ professional MBBS exam. This implied they had recently cleared their pharmacology exam. The other group consisted of interns in their last six months of compulsory rotatory residential internship (CRRI) schedule. Each group had two hundred entrants. The participants were included from medical colleges all across Telangana state. The state has a population of 3.9 crores with total of 20 medical colleges and 2600 MBBS seats. It was divided into four quadrants and medical colleges were randomly selected from each quadrant. The questionnaire with twenty items was uploaded in Google forms. The same was circulated with the help of website link to students and interns' whatsapp groups. Participation was entirely voluntary and they responded to the questions after they had given their consent. The respondents remained anonymous.

Likert scale was used to assess the attitude regarding generic drugs. IBM SPSS (windows version 24, Inc., Chicago, Illinois, USA) was used for statistical analysis. Mean, SD and percentages were calculated for generic variables like knowledge and attitude with $95 \%$ Confidence Intervals. Comparison of mean knowledge and attitude scores across participants was done using $\mathrm{t}$ test. Associations of these generic variables were assessed by chi square test. The level of significance was considered as 0.05 .

\section{RESULTS}

The total number of participants in the study was four hundred. Two hundred MBBS students and two hundred interns took part from medical colleges selected randomly across Telangana. The state was divided into four quadrants and medical colleges were arbitrarily chosen from each quadrant.

In assessing the knowledge level (Table 1) between the two groups, $95.1 \%$ of interns and $92.7 \%$ of students knew about generic drugs. $70.9 \%$ of interns agreed that brand name drugs can be interchanged with generic ones. Majority (83.7 of interns and 84.1 of students) opined that side effect profile was not adverse with generic drugs. $63.8 \%$ of students were aware of the Medical council of India regulations regarding prescription of generic drugs compared to a $56.7 \%$ of interns. A significant $(\mathrm{p}<0.05)$ number of students $(24.6 \%)$ felt that all brand name drugs 
were for serious illnesses, compared to $16.3 \%$ of interns. Significant $(\mathrm{p}<0.05)$ lower percentage $(79.8)$ of interns believed generic drugs could bring down the financial burden without affecting the treatment quality.

Table 1: Association of knowledge about generic drugs by students and interns.

\begin{tabular}{|c|c|c|c|c|c|c|}
\hline $\begin{array}{l}\text { Q. } \\
\text { no. }\end{array}$ & Variable & Category & $\begin{array}{l}\text { Interns } \\
(\mathbf{N}=\mathbf{2 0 3})\end{array}$ & $\begin{array}{l}\text { 3 }^{\text {rd }} \text { year MBBS } \\
(\mathrm{N}=\mathbf{2 3 2})\end{array}$ & $\begin{array}{l}\text { Chi } \\
\text { square }\end{array}$ & P value \\
\hline \multirow{2}{*}{1} & \multirow{2}{*}{ Do u know what are generic drugs } & Yes & 95.1 & 92.7 & \multirow{2}{*}{1.07} & \multirow{2}{*}{0.300} \\
\hline & & No & 4.9 & 7.3 & & \\
\hline \multirow{2}{*}{2} & \multirow{2}{*}{$\begin{array}{l}\text { Do you think Generic drugs are a replica/ copy of the } \\
\text { brand name drugs }\end{array}$} & Yes & 59.6 & 62.9 & \multirow{2}{*}{0.505} & \multirow{2}{*}{0.477} \\
\hline & & No & 40.4 & 37.1 & & \\
\hline \multirow{2}{*}{3} & \multirow{2}{*}{$\begin{array}{l}\text { Do you think Brand name drugs can be interchanged } \\
\text { with generic drugs }\end{array}$} & Yes & 70.9 & 69.8 & \multirow{2}{*}{0.064} & \multirow{2}{*}{0.801} \\
\hline & & No & 29.1 & 30.2 & & \\
\hline \multirow{2}{*}{4} & \multirow{2}{*}{$\begin{array}{l}\text { Do you think Therapeutic efficacy of brand name } \\
\text { drugs are same as generic drugs }\end{array}$} & Yes & 54.7 & 58.1 & \multirow{2}{*}{2.734} & \multirow{2}{*}{0.098} \\
\hline & & No & 45.3 & 41.9 & & \\
\hline \multirow{2}{*}{5} & \multirow{2}{*}{ Do you think Generic drugs have more side effects } & Yes & 16.3 & 15.9 & \multirow{2}{*}{0.008} & \multirow{2}{*}{0.931} \\
\hline & & No & 83.7 & 84.1 & & \\
\hline \multirow{2}{*}{6} & \multirow{2}{*}{$\begin{array}{l}\text { Is there any MCI (Medical Council of India) } \\
\text { regulation on generic drug prescription? }\end{array}$} & Yes & 56.7 & 63.8 & \multirow{2}{*}{2.311} & \multirow{2}{*}{0.128} \\
\hline & & No & 43.3 & 36.2 & & \\
\hline \multirow{2}{*}{7} & \multirow{2}{*}{ Are generic drugs available in your pharmacy? } & Yes & 52.2 & 56.9 & \multirow{2}{*}{0.957} & \multirow{2}{*}{0.328} \\
\hline & & No & 47.8 & 43.1 & & \\
\hline \multirow{2}{*}{8} & \multirow{2}{*}{$\begin{array}{l}\text { Brand name drugs have to meet higher levels of safety } \\
\text { and efficacy compared to generic drugs }\end{array}$} & Yes & 61.6 & 60.3 & \multirow{2}{*}{0.069} & \multirow{2}{*}{0.793} \\
\hline & & No & 38.4 & 39.7 & & \\
\hline \multirow{2}{*}{9} & \multirow{2}{*}{$\begin{array}{l}\text { Do you think Brand name drugs are for serious } \\
\text { illnesses }\end{array}$} & Yes & 16.3 & 24.6 & \multirow{2}{*}{4.559} & 0033 \\
\hline & & No & 83.7 & 75.4 & & 0.033 \\
\hline 10 & Do you think Generic drugs can reduce treatment cost & Yes & 79.8 & 87.5 & & \\
\hline & without affecting the quality of treatment & No & 20.2 & 12.5 & 4.750 & 0.029 \\
\hline
\end{tabular}

Table 2: Association of attitude about generic drugs by Interns and students.

\begin{tabular}{|c|c|c|c|c|c|c|}
\hline Q. no. & Variable & Category & Interns & $3^{\text {rd }}$ years & Chi square & P value \\
\hline \multirow{5}{*}{11} & \multirow{5}{*}{$\begin{array}{l}\text { Prescribing generic drugs } \\
\text { should be mandatory }\end{array}$} & Strongly agree & 14.3 & 11.6 & \multirow{5}{*}{1.897} & \multirow{5}{*}{0.755} \\
\hline & & Agree & 26.6 & 31 & & \\
\hline & & Neutral & 51.7 & 49.1 & & \\
\hline & & Disagree & 6.4 & 6.5 & & \\
\hline & & Strongly disagree & 1 & 1.7 & & \\
\hline \multirow{5}{*}{12} & \multirow{5}{*}{$\begin{array}{l}\text { Generic drugs take a longer } \\
\text { time to produce therapeutic } \\
\text { benefits }\end{array}$} & Strongly agree & 2 & 1.6 & \multirow{5}{*}{2.46} & \multirow{5}{*}{0.652} \\
\hline & & Agree & 17.2 & 16.1 & & \\
\hline & & Neutral & 28.1 & 30.3 & & \\
\hline & & Disagree & 38.4 & 39.5 & & \\
\hline & & Strongly disagree & 14.3 & 12.4 & & \\
\hline \multirow{5}{*}{13} & \multirow{5}{*}{$\begin{array}{l}\text { Your prescribing decision } \\
\text { will be/is influenced by } \\
\text { medical representative }\end{array}$} & Strongly agree & 0.5 & 3 & \multirow{5}{*}{8.449} & \multirow{5}{*}{0.076} \\
\hline & & Agree & 25.1 & 27.6 & & \\
\hline & & Neutral & 28.1 & 33.2 & & \\
\hline & & Disagree & 29.6 & 20.7 & & \\
\hline & & Strongly disagree & 16.7 & 15.5 & & \\
\hline \multirow{5}{*}{14} & \multirow{5}{*}{$\begin{array}{l}\text { There should be incentives } \\
\text { for prescribing generic } \\
\text { drugs }\end{array}$} & Strongly agree & 4.9 & 7.8 & \multirow{5}{*}{20.456} & \multirow{5}{*}{0} \\
\hline & & Agree & 29.1 & 43.5 & & \\
\hline & & Neutral & 34.5 & 33.6 & & \\
\hline & & Disagree & 22.7 & 11.2 & & \\
\hline & & Strongly disagree & 8.9 & 3.9 & & \\
\hline \multirow{5}{*}{15} & \multirow{5}{*}{$\begin{array}{l}\text { Brand name drugs from } \\
\text { multinational companies } \\
\text { are superior to generic } \\
\text { drugs from Indian } \\
\text { manufacturers }\end{array}$} & Strongly agree & 6.4 & 4.1 & \multirow{5}{*}{6.314} & \multirow{5}{*}{0.177} \\
\hline & & Agree & 25.6 & 24.6 & & \\
\hline & & Neutral & 24.1 & 25.7 & & \\
\hline & & Disagree & 30 & 29.7 & & \\
\hline & & Strongly disagree & 13.8 & 17.7 & & \\
\hline \multirow{2}{*}{16} & \multirow{2}{*}{$\begin{array}{l}\text { It is easier to remember a } \\
\text { brand name than a generic }\end{array}$} & Strongly agree & 2.5 & 1.3 & \multirow{2}{*}{16.92} & \multirow{2}{*}{0.002} \\
\hline & & Agree & 20.2 & 31.5 & & \\
\hline
\end{tabular}




\begin{tabular}{|c|c|c|c|c|c|c|}
\hline Q. no. & Variable & Category & Interns & $3^{\text {rd }}$ years & Chi square & P value \\
\hline & \multirow[t]{3}{*}{ name of a drug } & Neutral & 18.7 & 26.7 & & \\
\hline & & Disagree & 35 & 26.3 & & \\
\hline & & Strongly disagree & 23.6 & 14.2 & & \\
\hline \multirow{5}{*}{17} & \multirow{5}{*}{$\begin{array}{l}\text { Government should take } \\
\text { strong steps to implement } \\
\text { generic prescribing of } \\
\text { drugs? }\end{array}$} & Strongly agree & 28.1 & 25.4 & \multirow{5}{*}{1.317} & \multirow{5}{*}{0.858} \\
\hline & & Agree & 47.8 & 53 & & \\
\hline & & Neutral & 20.7 & 19 & & \\
\hline & & Disagree & 3 & 2.2 & & \\
\hline & & Strongly disagree & 0.5 & 0.4 & & \\
\hline \multirow{5}{*}{18} & \multirow{5}{*}{$\begin{array}{l}\text { There should be no } \\
\text { incentives for prescribing } \\
\text { brand name drugs }\end{array}$} & Strongly agree & 15.3 & 9.5 & \multirow{5}{*}{13.266} & \multirow{5}{*}{0.01} \\
\hline & & Agree & 41.9 & 31 & & \\
\hline & & Neutral & 31.5 & 42.2 & & \\
\hline & & Disagree & 7.9 & 13.8 & & \\
\hline & & Strongly disagree & 3.4 & 3.4 & & \\
\hline \multirow{5}{*}{19} & \multirow{5}{*}{$\begin{array}{l}\text { Indian manufacturers are } \\
\text { following the good } \\
\text { manufacturing practices } \\
\text { (GMP) guidelines as } \\
\text { multinational companies }\end{array}$} & Strongly agree & 4.4 & 4.3 & \multirow{5}{*}{9.4909} & \multirow{5}{*}{0.052} \\
\hline & & Agree & 26.1 & 38.8 & & \\
\hline & & Neutral & 56.7 & 46.1 & & \\
\hline & & Disagree & 8.4 & 8.6 & & \\
\hline & & Strongly disagree & 4.4 & 2.2 & & \\
\hline \multirow{5}{*}{20} & \multirow{5}{*}{$\begin{array}{l}\text { Generic drugs are for poor } \\
\text { patients }\end{array}$} & Strongly agree & 7.4 & 9.1 & \multirow{5}{*}{2.084} & \multirow{5}{*}{0.72} \\
\hline & & Agree & 19.7 & 18.1 & & \\
\hline & & Neutral & 25.1 & 23.3 & & \\
\hline & & Disagree & 30 & 34.9 & & \\
\hline & & Strongly disagree & 17.7 & 14.7 & & \\
\hline
\end{tabular}

While we looked into the attitude of two groups (Table 2), only $14.3 \%$ of interns and $11.3 \%$ of students strongly opined that prescribing generic drugs should be mandatory. $1.0 \%$ of interns and $1.7 \%$ of students strongly disagreed for the same. Majority in both the groups maintained a neutral opinion. $38.4 \%$ of interns and $39.5 \%$ of students disagreed that generic drugs take a longer time to produce therapeutic benefits $(\mathrm{p}>0.05)$. Higher percentage (29.6) of interns compared to students (20.7) of students disagreed that their prescribing decision will be influenced by medical representatives. Significant $(\mathrm{p}<0.001)$ number of students $(43.5 \%)$ opined that there should be incentives for prescribing generic drugs compared to interns (29.1\%). $30 \%$ of interns and $29.7 \%$ of students disagreed on the point that, brand name drugs from multinational companies were superior to generic drugs from Indian manufacturers $(p>0.05)$. Significant $(p<0.01)$ interns $(35.5 \%)$ did not agree that was easier to remember a brand name than a generic name, compared to students (26.3\%). $47.8 \%$ of interns and $53.3 \%$ of students felt that Government should take strong steps to implement generic prescribing of drugs $(p>0.05)$. Higher percentage $(41.9)$ of interns agreed $(p<0.01)$ that there should be no incentives for prescribing brand name drugs compared to students $(31 \%)$. Regarding the incentivisation aspect, more of students (43.5\%) felt generic drugs should have benefits related to their prescribing and only $29.1 \%$ of interns thought the same $(\mathrm{p}<0.01)$.

Only $4.4 \%$ of interns and $2.2 \%$ of students strongly felt that Indian manufacturers were not following the good manufacturing practices (GMP) guidelines as multinational companies ( $p>0.05) .30 \%$ of interns and $34.9 \%$ of students disagreed that generic drugs are for poor patients $(\mathrm{p}>0.05)$.

Table 3: Mean and $95 \%$ confidence interval of knowledge and attitude of participants.

\begin{tabular}{|c|c|c|c|}
\hline Participants & $\begin{array}{l}\text { Sample } \\
\text { size }(\mathbf{N})\end{array}$ & Knowledge & Attitude \\
\hline Interns & 203 & $\begin{array}{l}67.5 \\
(65.0-70.0)\end{array}$ & $\begin{array}{l}48.6 \\
(45.5-51.8)\end{array}$ \\
\hline $\begin{array}{l}3^{\text {rd }} \text { year MBBS } \\
\text { students }\end{array}$ & 232 & $\begin{array}{l}69.5 \\
(67.3-71.7)\end{array}$ & $\begin{array}{l}44.6 \\
(41.7-47.4)\end{array}$ \\
\hline Total & 435 & $\begin{array}{l}68.6 \\
(66.9-70.2)\end{array}$ & $\begin{array}{l}46.5 \\
(44.3-48.6)\end{array}$ \\
\hline$P$ value & & 0.227 & 0.060 \\
\hline
\end{tabular}

In assessing the attitude and knowledge about prescription of generic drugs among 232 students and 203 interns of means with $95 \%$ confidence interval, mean was similar for both the students and interns in both the parameters of knowledge and attitude, $67.5 \%$ of interns and $69.5 \%$ of students had similar knowledge about generic drugs. There was a slight trend or increase in the attitude towards generic drugs in the intern group of $48.6 \%$ when compared to students of $44.6 \%$, it is not statistically significant. $20.2 \%$ of intern and $19.8 \%$ of students had knowledge score of less than 60.

$38.9 \%$ of interns and $38.8 \%$ of students had knowledge score of $60-80.40 .9 \%$ of interns and $41.4 \%$ of students had knowledge score of more than or equal to 80 . 
Table 4: Association of knowledge of participants.

\begin{tabular}{|c|c|c|c|c|}
\hline $\begin{array}{l}\text { Knowledge } \\
\text { score }(\%)\end{array}$ & Interns & $\begin{array}{l}3^{\text {rd }} \text { year } \\
\text { MBBS } \\
\text { students }\end{array}$ & $\begin{array}{l}\text { Chi } \\
\text { square } \\
\text { value }\end{array}$ & $\begin{array}{l}\mathbf{P} \\
\text { value }\end{array}$ \\
\hline$<60$ & 20.2 & 19.8 & \multirow{3}{*}{0.014} & \multirow{3}{*}{0.993} \\
\hline $60-80$ & 38.9 & 38.8 & & \\
\hline$\geq \mathbf{8 0}$ & 40.9 & 41.4 & & \\
\hline
\end{tabular}

The proportion of knowledge scores (Table 4) was similar in both the groups of students and interns. The knowledge scores are based on the tertile values, such that $<60$ corresponds to $33.3 \%, 60-80$ to $66.7 \%$ and $\geq 80$ is more than $66.7 \%$.

$29.1 \%$ of intern and $34.9 \%$ of students had attitude score of less than $60.33 \%$ of interns and $32.8 \%$ of students had attitude score of $60-80.37 .9 \%$ of interns and $32.3 \%$ of students had attitude score of more than or equal to 80 .

Table 5: Association of attitude of participants.

\begin{tabular}{|c|c|c|c|c|}
\hline $\begin{array}{l}\text { Attitude } \\
\text { score }\end{array}$ & Interns & $\begin{array}{l}3^{\text {rd }} \text { year } \\
\text { MBBS } \\
\text { students }\end{array}$ & $\begin{array}{l}\text { Chi } \\
\text { square } \\
\text { value }\end{array}$ & $P$ value \\
\hline$<60$ & 29.1 & 34.9 & \multirow{3}{*}{2.126} & \multirow{3}{*}{0.345} \\
\hline $60-80$ & 33.0 & 32.8 & & \\
\hline$\geq 80$ & 37.9 & 32.3 & & \\
\hline
\end{tabular}

The proportion of attitude scores (Table 5) was similar in both the groups of students and interns. The knowledge scores are based on the tertile values, such that $<60$ corresponds to $33.3 \%, 60-80$ to $66.7 \%$ and $\geq 80$ is more than $66.7 \%$.

\section{DISCUSSION}

According to National Health Accounts Estimates of India (NHAEI) prepared by the Minister of Health and Family Welfare (MOHFW), New Delhi, Telangana spent Rs 1,019 per person every year. In comparison USA spends approximately Rs 70,000/- per person per year. India's total healthcare spending (out-of-pocket and public), at $3.6 \%$ of GDP, is way lower than that of other countries.

One of the major expense area in the healthcare segment was towards medicines. Pradhan Mantri Bhartiya Janaushadhi Pariyojana (PMBJK) campaign was initiated by the government of India and one of the significant observations was 'non-prescription of generic drugs'. The knowledge level regarding generic drugs was adequate among both the participant groups in our study. This is different from the study done by Deb et al done at Kohlapur, Maharashtra wherein they found a deficiency in the overall knowledge. ${ }^{7}$ Both the groups in our study, were aware of the medical council of India (MCI) regulations regarding generic prescription and were agreeable on terms that branded drugs can be interchanged with generic versions. In our state, majority of both the students $(84.1 \%)$ and interns group $(83.7 \%)$ knew that generic drugs do not produce more side effects, which is similar to the Kohlapur, Maharashtra study. ${ }^{7}$ This was different from the study done at Nepal by Gyawali et al, where $17 \%$ of the participants thought generic medicines are less effective and produce more side effects compared to brand-name medicines while almost $25 \%$ neither agreed or disagreed to the point. ${ }^{8}$ In our study, more of MBBS students $(24.6 \%)$ believed that serious ailments required brand drugs. On the other hand, the same group (87.5\%) felt that generic drugs could decrease the financial burden on patients without affecting the quality of treatment. The intern group had some reservations regarding the same. This means that the understanding and theoretical knowledge of generic drugs among students was adequate, but once they moved on in their course and saw the practical scenario skepticism set in. This could be attributed to the fact that the interns had a change of mindset, observing their seniors' practices. A systematic review conducted by Colgan et al brought out negative attitude about generics not only in pharmacists and doctors, but also among lay people. ${ }^{9}$ Quality checks and trust in medicine quality must be implemented from the top which will then percolate down.

The new competency based medical education (CBME) curriculum by MCI also provides a scope in the form of 'electives'. Medical colleges can innovate in this aspect and can design electives in a generic drug manufacturing units or in certified laboratories doing pharmacokinetic/ pharmacodynamic (PK/PD) studies. This can give a practical 'hands on' experience to medical graduates and therefore better ingrained memory.

Majority in both the MBBS students and the interns maintained neutrality whether prescribing generics drugs should be mandatory. There was a favourable trend in the interns group regarding medical representatives' influence on their prescribing habits. And most of them (35.5\%) disagreed that remembering brand names were any easier. This was a positive aspect of our study which implied that if concept/names of generics were more and repetitively stressed upon, it could bring about a palpable change in attitude. Later on, it would translate into a change in practices. The concepts of generic drugs could be reintroduced in later stages of medical career by promoting more research in generic drugs. Hospital formularies of the medical colleges could store more of generic drugs, thereby exposing the interns and the senior faculty to their use. A brief exposure to pharmacoeconomics could be introduced in the CRRI period, wherein they could understand the financial privileges of generic drugs. All these measures would also ensure that the individual had repetitive encounters about generics, instead of a onetime affair of pharmacology classes in MBBS curriculum. More of students felt incentives should be given for prescribing generic drugs, and more of interns (41.9\%) felt there shouldn't be any incentives for brand drugs. The entire trend is towards generic drugs and the Government along with regulatory 
authorities can consider incentivisation along with quality checks to boost the Pradhan Mantri Bhartiya Janaushadhi Pariyojana (PMBJK) campaign. Majority in both the participant groups (30\% of interns and $34.9 \%$ of students) disagreed that generics were for poor population. On extrapolation of this attitude, it can be deciphered they are ready to prescribe generics irrespective of patients' financial status. Neither do they have a doubt about Indian pharmaceutical manufacturers complying with good manufacturing practices (GMP) guidelines. In a study done at Turkey, $70 \%$ of the respondents opined that generics were as good as brand drugs and the country was experiencing an increase in the use of generics.10 Generics can make medical costs cheaper and also ensure sound treatment options for the patients. ${ }^{11}$

\section{CONCLUSION}

Our study revealed a similar knowledge level about generic in both students and interns groups. $40.9 \%$ of interns and $41.4 \%$ of students had a knowledge score of more than or equal to 80 .

Both were of the opinion that generics and brand drugs could be prescribed interchangeably and that the former did not have an unfavourable safety profile in comparison with the later. Interns did not agree with incentivisation of brand drugs and disagreed that recollecting brand names were any easier. However both groups maintained neutrality regarding mandatory prescribing of generics. $37.9 \%$ of interns and $32.3 \%$ of students had an attitude score of more than or equal to 80 . Therefore implementation of certain practices like stocking of more generics at medical college pharmacies, more research and incentivisation of generic drug use could translate into a rise of generic usage. Last but not the least there should be an effective interplay between healthcare providers and higher regulatory officials. All these could bring down medical costs and complement the low governmental healthcare spending.

\section{ACKNOWLEDGEMENTS}

We thank all the MBBS students and the interns of medical colleges across Telangana who agreed to be a part of the study and expressed their opinion. We are thoroughly indebted to Dr Nagalla Balakrishna head of the department of Statistics of our institute. He has been generous to statistically analyse our data.

Funding: No funding sources Conflict of interest: None declared

Ethical approval: The study was approved by the Institutional Ethics Committee

\section{REFERENCES}

1. World Health Organization (WHO). Generic drugs. Geneva: WHO; 2015. http://www.who.int/trade/ glossary/story034/en/index.html. Accessed 21 June 2015.

2. Kefalas CH, Ciociola AA. The FDA's generic-drug approval process: similarities to and differences from brand name drugs. Am J Gastroenterol. 2011;106:1018-21.

3. Dunne S, Shannon B, Dunne C, Cullen W. A review of the differences and similarities between generic drugs and their originator counterparts, including economic benefits associated with usage of generic medicines, using Ireland as a case study. BMC Pharmacol Toxicol. 2013;14:1.

4. Revised checklist for BA/BE NOC effective from $01^{\text {st }}$ February 2014. Cdsco.nic.in. Available from: https://cdsco.gov.in/opencms/resources/UploadCDSC OWeb/2018/UploadAlertsFiles/BABwebsite\%20201 4 reviseddocumentrequired.pdf. Accessed on 12 April 2018.

5. Medical Council of India: Circular on Generic Medicine. 2017. Available from: https://old.mciindia. org/circulars/Public-Notice-Generic-Drugs21.04.2017.pdf. Accessed on 5 June 2017.

6. Approved drug products with therapeutic equivalence evaluations (Orange Book) Available from: https://www.fda.gov/drugs/informationondrugs/ucm1 29662.htm. Accessed on 15 October 2018.

7. Deb A, Dhavalshankh AG, Burande MA, Patil SS, Tahashildar JC. Evaluation of knowledge, attitude and perception about generic medicines among medical students and interns in a tertiary care hospital. J Adv Med Dent Sci Res. 2017;5(11):8-12.

8. Gyawali S, Hassali MA, Saha A. A survey exploring the knowledge and perceptions of senior medical students in Nepal toward generic medicines. SAGE Open Med. 2016;4:2050312116662570.

9. Colgan S, Faasse K, Martin LR, Stephens MH, Grey A, Petrie KJ. Perceptions of generic medication in the general population, doctors and pharmacists: a systematic review. BMJ Open. 2015;5(12).

10. Toklu HZ, Dülger GA, Hidiroğlu S, Akici A, Yetim A, Gannemoğlu HM, Güneş H. Knowledge and attitudes of the pharmacists, prescribers and patients towards generic drug use in Istanbul-Turkey. Pharm Pract. 2012;10(4):199-206.

11. Joshi SS, Shetty YC, Karande S. Generic drugs- the Indian scenario. J Postgrad Med. 2019;65(2):67-9.

Cite this article as: Sen S, Kumar BN. Attitude and knowledge towards prescription of generic drugs: online study across Telangana. Int J Basic Clin Pharmacol 2020;9:1375-80. 